\title{
Beclin1 enhances cisplatin-induced apoptosis via Bcl-2-modulated autophagy in laryngeal carcinoma cells Hep-2
}

\author{
M. YANG, X.M. YANG, D.H. YIN, Q.L. TANG, L. WANG, C. HUANG, P. LI, S.S. LI* \\ Department of Otolaryngology, Head and Neck Surgery, the Second Xiangya Hospital, Central South University, Changsha 410011, Hunan, PR \\ China
}

${ }^{*}$ Correspondence: lissdoctor@sina.com

Received November 2, 2016/ Accepted May 3, 2017

\begin{abstract}
To investigate the role of Beclin1 in cisplatin-induced apoptosis in laryngeal carcinoma cells Hep-2 and to explore the potential mechanism. We up-regulated Beclin1 expression in Hep-2 cells. The survival rate and apoptotic rate were evaluated by MTT and flow cytometry (FCM). The Beclin1 overexpression group and the control group were treated with cisplatin for 24 hours. The proliferation and cell apoptosis of laryngeal cancer cell lines were evaluated. The mitochondrial membrane potentials were detected by DiOC6(3). Activities of Caspase-8/9/3 and convention of microtubule-associated protein one light chain 3 (LC3) were detected by western blot. The effect of Bcl-2 overexpression on increased cisplatin-sensitivity and autophagy induced by Beclin1 was investigated using Bcl-2 cDNA transfection. Expression of Beclin1 in Hep-2 cells was meaningfully enhanced by transfection, and the proliferation and the apoptosis were not considerably affected. By cisplatin treatment, the Beclin 1 overexpression group showed lower survival rate and higher apoptotic rate than the control group $(\mathrm{p}<0.05)$. Decrease of mitochondrial membrane potential and increase of activities of Caspase- 8 , Caspase- 9 and Caspase- 3 were detected. Beclin 1 overexpression increase the convention of LC3, especially after the cisplatin treatment. Overexpression of Bcl-2 decreased the cisplatin-induced apoptosis and inhibited Beclin1-induced autophagy. In conclusion, Beclin1 enhances cisplatin-induced apoptosis in laryngeal carcinoma cells Hep-2 via Bcl-2 modulated autophagy.
\end{abstract}

Key words: laryngeal carcinoma, Beclin1, cisplatin, autophagy, Bcl-2

Laryngeal carcinoma, classified as squamous cell carcinoma (LSCC) in $90 \%$ of the cases, is one of the most common malignant tumors of head and neck region in the world [1]. Despite substantial improvements in the diagnosis and treatment of laryngeal carcinoma during the last decades, no significant increase in the long-term survival rate has been achieved [2]. Five-year survival rate is about 63\% in America [3]. New treatment methods that provide more efficient results are highly desirable. Novel targets that can serve as the foundation of biologically based therapeutic strategies are needed.

Autophagy is important for maintaining the stability of cells and some physiological functions of cells, such as meeting the requirement of metabolism and updating some organelles under a physiological or pathological situation [4-6]. Autophagy is rapidly induced during nutritional deficiency, oxidative stress, infection or ischemia-reperfusion [7-8]. It has been found that autophagy has both promoting and suppressive effects in different stages of the cancer development [9-10]. Ongoing studies aim at finding the optimal means to regulate autophagy in cancer preven- tion and treatment. In our previous study [11], we detected the expression of Beclin1 in laryngeal cancer specimens. The results showed that Beclin1 expression in LSCC was significantly lower compared to the para-carcinoma tissue. The expression of Beclin1 in tumor tissues was significantly lower than in the non-tumor tissues. Reduced Beclin 1 expression was significantly correlated with lymph node metastases. Kaplan-Meier survival estimates showed a significant correlation between Beclin1 expression and patient's survival rate. Thus, the expression level of Beclin 1 is closely associated with the laryngeal cancer cell's ability of invasion and metastasis. So we detect the influence of Beclin1 expression on cisplatin sensitivity in laryngeal carcinoma cells Hep-2 and explore the potential mechanism.

\section{Materials and methods}

Cell lines and reagents. The human laryngeal carcinoma cells Hep-2 were kindly provided by the Department of Otolaryngology and Head and Neck Surgery, Xiangya 
Second Hospital of Central South University (Changsha, China). All cells were cultured in RPMI-1640 (Invitrogen, Carlsbad, USA) media supplemented with $10 \%$ fetal bovine serum (Hyclone, Logan, USA) and penicillin/streptomycin, and maintained in a humidified atmosphere of $5 \% \mathrm{CO}_{2}$ at $37^{\circ} \mathrm{C}$. Cisplatin was purchased from Blue skies biological preparation Co., Ltd. Drugs were dissolved in DMSO in appropriate concentration and stored at $-20^{\circ} \mathrm{C}$ until used. The following antibodies were purchased from the indicated sources: Rabbit anti-Beclin1 polyclonal antibody, rabbit anti-Caspase- 9 polyclonal antibody, rabbit anti-Caspase- 8 polyclonal antibody and rabbit anti-Caspase-3 polyclonal antibody (Sigma co., United States), mouse anti-Bcl-2 polyclonal antibody, mouse anti-LC polyclonal antibody (Santa Cruz, CA, United States). Cell viability was determined by using 3-(4, 5-dimethylthiazolyl)-2, 5-diphenyltetrazoliumbromide (MTT) assays. Cells (5 000 cells per well) were plated in 96-well plates. After the indicated cisplatin treatment dose (cisplatin doses were from 0 to $10 \mu \mathrm{g} / \mathrm{mL}$ ) for 24 hours, cells were incubated for 2-3 hours with $0.5 \mathrm{mg} / \mathrm{mL}$ of MTT (Sigma, USA) and lysed with dimethyl sulfoxide (DMSO). The optical density (OD) of each well was measured at $570 \mathrm{~nm}$ with a microplate reader. Inhibit rate $=\left(\mathrm{OD}_{\text {control }}-\mathrm{OD}_{\text {treat }}\right) / \mathrm{OD}_{\text {control }}$.

Apoptosis assessment by Annexin V/PI staining. Levels of cisplatin-mediated apoptosis were determined by using Annexin V/PI staining kit. After the indicated cisplatin treatment or time points, cells were harvested. Cell pellets were suspended in $500 \mu \mathrm{L}$ binding buffer $(10 \mathrm{mM}$ HEPES, $\mathrm{pH} 7.4,140 \mathrm{mM} \mathrm{NaCl}, 1 \mathrm{mM} \mathrm{MgCl}, 5 \mathrm{mM} \mathrm{KCl}, 2.5 \mathrm{mM}$ $\left.\mathrm{CaCl}_{2}\right)$ at the density of $1 \times 10 \% \mathrm{~mL}$. Samples were incubated with $1 \mu \mathrm{L}$ Annexin V-FITC and $5 \mu \mathrm{L}$ PI for exactly $5 \mathrm{~min}$ at room temperature in the dark and then measured on a FACSort flow cytometer (Becton Dickinson, USA). Annexin V-FITC and PI fluorescence were detected in the FL-1 (green) and FL-2 (red) channels respectively, after correction of the spectral overlap between the two channels. Data were analyzed by using CellQuest software.

Beclin1 cDNA transfection. Beclin1-expression vector (pcDNA3.1-Beclin1) and pcDNA3.1 vectors were purchased from Beyotime Institute of Biotechnology China. Transfection was performed using Lipofectamine 2000 (Invitrogen) according to the manufacturer's instructions. In brief, cells were seeded into wells of a 6-well plate at $10^{5}$ cells $/ \mathrm{cm}^{2}$ and cultured for 24 hours until $60-70 \%$ confluence. Then pcDNA3.1-Beclin1 or negative pcDNA3.1 vector $(4 \mu \mathrm{L})$ was diluted with $100 \mu \mathrm{L}$ OPTI-MEM (Invitrogen) for $5 \mathrm{~min}$ at room temperature. During the incubation period, $5 \mu \mathrm{L}$ Lipofectamine 2000 (Invitrogen) was diluted in $100 \mu \mathrm{L}$ OPTI-MEM. These two mixtures were combined, mixed gently, and incubated for $20 \mathrm{~min}$ at room temperature for complex formation. This $200 \mu \mathrm{L}$ mixture was then added to cells. After 48 hours of incubation, transfected cells could be observed by the fluorescence microscope. Transfected cells were selected in cell culture medium containing $700 \mu \mathrm{g} / \mathrm{mL}$
G418 (Invitrogen). After 2 or 3 weeks, mixtures of all the selection resistant cell clones were seeded into wells of a 6-well plate and cultured.

Western blot analysis. Total protein lysates were harvested from tissue specimens and cell lines by lysis buffer $(20 \mathrm{mM}$ $\mathrm{Na}_{2} \mathrm{PO}_{4}, 150 \mathrm{mM} \mathrm{NaCl}, 1 \%$ Triton X-100, $1 \%$ aprotinin, $1 \mathrm{mM}$ phenylmethylsulfonyl fluoride, $100 \mathrm{mM} \mathrm{NaF}$, and $2 \mathrm{mM} \mathrm{Na}_{3} \mathrm{VO}_{4}$ ). Proteins $(50 \mu \mathrm{g})$ were separated by polyacrylamide gel electrophoresis (SDS-PAGE) on a sodium dodecyl sulfate-polyacrylamide gel and transferred to a polyvinylidene difluoride membrane. Membranes were incubated with the first antibody. After 2 hours, the membranes were washed with Tris Buffered Saline and Tween-20 (TBST) three times and then the membranes were incubated with horseradish peroxidase conjugated rat anti-rabbit secondary antibody. Finally, proteins were detected by enhanced chemiluminescence (ECL) procedure.

Assessment of mitochondrial transmembrane potential. Assessment of mitochondrial transmembrane potential $\mathrm{D}$ ym by the cationic lipophilic fluorochrome $3,3^{3}$-dihexyloxacarbo-cyanide iodide $\left(\mathrm{DiOC}_{6}(3)\right)(460 \mathrm{ng} / \mathrm{mL}$, Molecular Probes, Eugene, OR, USA) was used to measure the mitochondrial transmembrane potential. Cells were treated for 12 hours with TRAIL $(100 \mathrm{ng} / \mathrm{mL})$, then incubated for $30 \mathrm{~min}$ at $37.8^{\circ} \mathrm{C}$ in complete media with DiOC6, washed twice with PBS and analyzed in a FACSort flow cytometer.

Bcl-2 cDNA transfection. Bcl-2-expression vector (pcDNA3.1-Bcl-2) and pcDNA3.1 vector were purchased from Beyotime Institute of Biotechnology China. Transfection was performed using Lipofectamine 2000 (Invitrogen) according to the manufacturer's instructions. Transfected cells could be observed by fluorescence microscope.

Statistical analysis. All statistical analyses were performed using Supplementary Power Supply Set (SPSS) version 16.0 software, with the results expressed as mean $\pm \mathrm{SD}$ as appropriate. Results were considered statistically significant at $\mathrm{p}<0.05$ obtained with $\mathrm{t}$ test.

\section{Results}

Beclin1 expression level was enhanced without effect on proliferation and apoptosis. To determine the influence of pcDNA3.1-Beclin1 transfection on Hep-2 cells, western blot was performed to analyze Beclin1 protein level. As shown in Figure 1, the expression of Beclin1 in Hep-2 cells was improved by pcDNA3.1-Beclin1 transfection effectively. PcDNA3.1-Beclin1 transfection group showed a higher expression level of Beclin1, compared to blank vector control group and Hep- 2 cells group $(\mathrm{p}<0.05)$. After comparing the results of 24 hours, 48 hours and 72 hours respectively, we found that Beclin-1 overexpression had no obvious effect on the OD value and the apoptotic rate $(\mathrm{p}>0.05)$ by MTT and FCM (Figure 2).

Beclin1 overexpression enhanced cisplatin sensitivity. The inhibition rate was determined by MTT after the treat- 


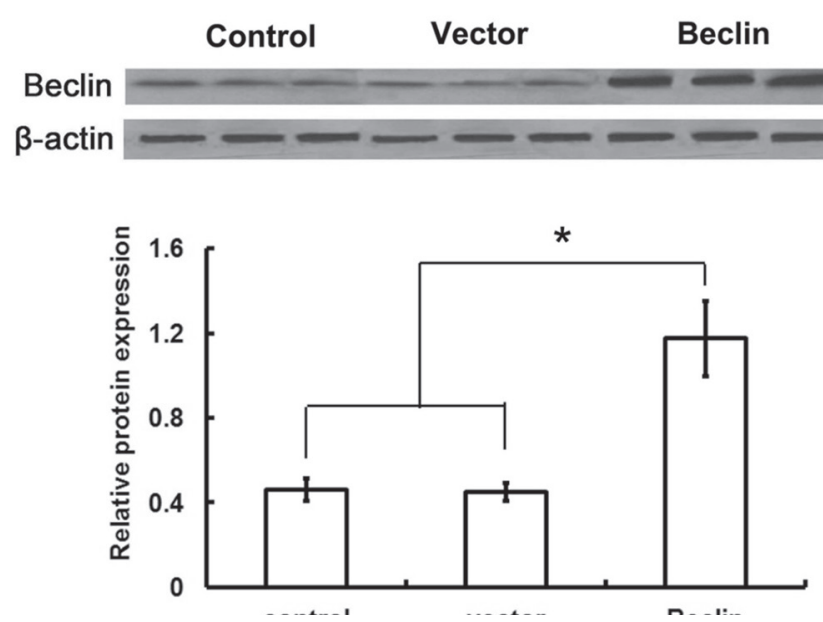

Figure 1. Beclin1 expression level was enhanced. A) Protein expression level of Beclin1 was assessed by western blot after pcDNA3.1-Beclin1 transfection to Hep-2 cells. B) PcDNA3.1-Beclin1 transfection group showed higher relative protein expression level of Beclin1 compared to blank vector control group and Hep-2 cells group $(p<0.05)$. (Control: control group, Vector: blank vector group, Beclin: pcDNA3.1-Beclin1 transfection group).

ment with different concentrations of cisplatin $(0 \mu \mathrm{g} / \mathrm{mL}$, $1 \mu \mathrm{g} / \mathrm{mL}, 2 \mu \mathrm{g} / \mathrm{mL}, 4 \mu \mathrm{g} / \mathrm{mL}, 6 \mu \mathrm{g} / \mathrm{mL}, 8 \mu \mathrm{g} / \mathrm{mL}, 10 \mu \mathrm{g} / \mathrm{mL})$ for 24 hours. The inhibition rate of Beclin1 in overexpression group was higher than in the two other groups when cells were treated with cisplatin of $6 \mu \mathrm{g} / \mathrm{mL}, 8 \mu \mathrm{g} / \mathrm{mL}$ and $10 \mu \mathrm{g} / \mathrm{mL}(\mathrm{p}<0.05)$. However, in the control group and blank vector group there is no statistical difference $(\mathrm{p}>0.05)$ (Figure 3A). We further analyzed the apoptosis rate by using FCM to confirm whether the differences in cell death were caused by different apoptotic responses. We assessed the apoptotic rate after the treatment with $10 \mu \mathrm{g} / \mathrm{ml}$ cisplatin for 24 hours. The apoptotic rate was $30.25 \pm 4.272 \%$ in Beclin 1 overexpression cells, which was significantly higher than that in the control group $(20 \pm 3.367 \%)$ and the vector group $(19 \pm 6.782 \%)(\mathrm{p}<0.05)$ (Figure 3B). As a result, the Beclin1 overexpression could enhance cisplatin sensitivity in laryngeal carcinoma cells.

Beclin1 overexpression induced Caspase cleavage and mitochondrial depolarization. To elucidate the molecular mechanism responsible for Beclin1-induced cisplatin sensitivity, we examined the effect of Beclin1 on the cisplatininduced apoptotic pathway. Analysis of Caspase activation showed that the cleaved and mature forms of Caspase- 8 (p43/41), Caspase-9 (p35) and Caspase-3 (p17, p10) were generated in cells during $10 \mu \mathrm{g} / \mathrm{ml}$ cisplatin for 24 hours (Figure 4A). Beclin 1 overexpression cells showed more Caspase activation after cisplatin treatment than the other two cell lines. This observation indicated that Beclin1 enhanced cisplatin-induced Caspase cleavage. As shown in Figure 4B, the DiOC6 (3) negative cell rate was lower in blank vector group and control group compared to the Beclin1 overexpression group during cisplatin treatment. The DiOC6 (3)
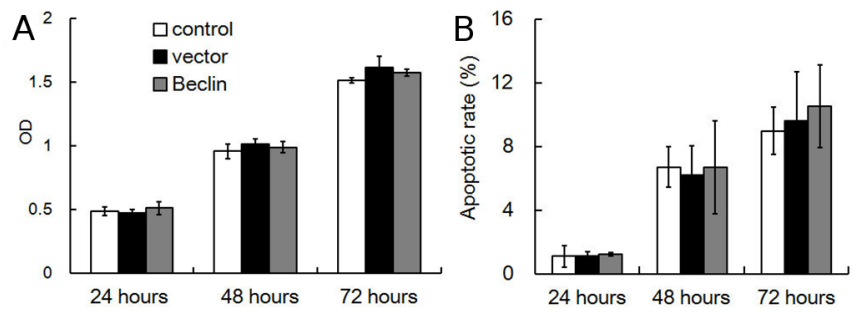

Figure 2. Beclin1 overexpression did not effect the proliferation and apoptosis of laryngeal carcinoma cells. A) The proliferation of Hep-2 cell was assessed by MTT. B) The apoptotic rate was assessed by FCM. Apoptotic ratio was determined by percentage of Annexin V+ PI- cells. OD value and apoptotic rate did not differ among the three cell groups statistically $(p>0.05)$.
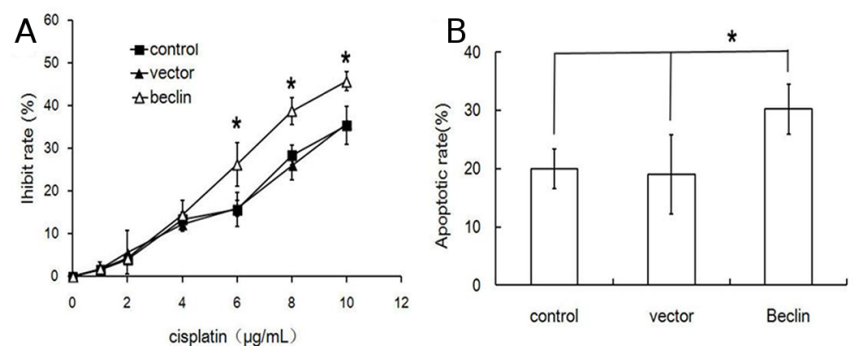

Figure 3. Beclin1 overexpression enhanced cisplatin-induced apoptosis. A) The inhibition rate was assessed by MTT after different concentrations of cisplatin treatment. The inhibition rate of Beclin1 overexpression group was higher than in the two other groups when cells were treated with cisplatin of $6 \mu \mathrm{g} / \mathrm{mL}, 8 \mu \mathrm{g} / \mathrm{mL}$ and $10 \mu \mathrm{g} / \mathrm{mL}$. B) The apoptotic rate of Beclinl overexpression cells was significantly higher than that in the other groups $\left({ }^{*} \mathrm{p}<0.05\right)$.
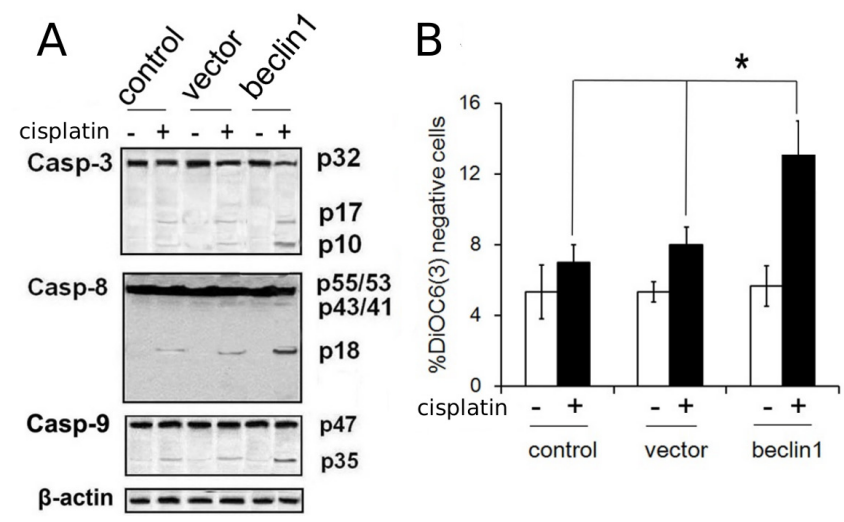

Figure 4. Beclin1 overexpression induced caspase cleavage and mitochondrial depolarization during cisplatin treatment. A) Cleavage of caspases was detected by western blot. Beclin 1 overexpression group showed more caspase cleavage after the cisplatin treatment $(10 \mu \mathrm{g} / \mathrm{mL}$ cisplatin, for $24 \mathrm{~h}$ treatment) than the two other groups. B) The mitochondrial membrane potential was detected by DiOC6(3). The DiOC6 (3) negative cell rate in Beclin1 overexpression group was higher than that in the two other groups during cisplatin treatment $\left({ }^{*} \mathrm{p}<0.05\right)$. (control: control group, vector: blank vector group, Beclin1: Beclin1 overexpression group).

negative cell indicated more mitochondrial depolarization. This result suggested that mitochondrial depolarization was enhanced by Beclin1 overexpression $(\mathrm{p}<0.05)$. This finding 
suggested that Beclin1, an autophagy gene, could induce the apoptosis of laryngeal carcinoma cancer cells in a mitochondrial-dependent mechanism.

Beclin1 overexpression enhanced cisplatin-induced apoptosis via Bcl-2 modulated autophagy. Beclin1 is an important factor of autophagy [12-13], therefore, we hypothesized that the Beclin1 overexpression enhanced cisplatininduced apoptosis via autophagy. To evaluate the autophagy induced by Beclin1, we observed the conversion of microtubule-associated protein 1 light chain 3 (LC3) in cells treated by cisplatin via western blot. An attenuation of LC3-I and an increase of LC3-II were observed in Beclin1 overexpression cells. With the cisplatin treatment, conversion of LC3 was detected in all cell groups, and was most obvious in Beclin1 overexpression cells (Figure 5). Bcl-2 binds to Beclin1 and inhibits conventional autophagy pathway in some conditions [14]. Therefore, we verified whether Bcl-2 overexpression inhibits biological behavior of Beclin1. We found that overexpression of Beclin 1 decreases the protein level of Bcl-2 (Figure 6A). As shown in Figure 6B, pcDNA3.1-Bcl-2 transfection decreased apoptotic rate in three groups. Moreover, we found that Bcl-2 overexpression might inhibit cisplatininduced apoptosis more obviously in Beclin-1 overexpression Hep-2 cells (the p-value in control cell group and vector control group $<0.05$, the $\mathrm{p}$-value in Beclin 1 overexpression group <0.01). Bcl-2 overexpression decreased LC3 conversion in Beclin 1 overexpression cells, and more obviously after cisplatin treatment (Figure 6C, D). This result confirms that Beclin1 overexpression enhanced cisplatin-induced apoptosis via Bcl-2 modulated autophagy.

\section{Discussion}

Some studies have shown that inducing apoptosis of cancer cells can assist tumor treatment. However, several mutations in apoptosis-induced genes of cancer cells inhibit the normal apoptosis induction. In recent years, some studies have shown that many antitumor drugs can kill tumor cells effectively via overexpression of Beclin 1 , and that the overexpression of Beclin 1 is a promising candidate for cancer therapy via induction of autophagy [15]. Beclin1, the homolog of the yeast Apg6 gene [16], is the first founded operational gene which takes part in autophagy [17]. The Beclin1 protein contains four functional structure domains: Bcl-2-homology-3 (BH3), central coiled coil domain (CCD), evolutionarily conserved domain (ECD) and nuclear output structure domain [18]. These domains can form "Beclin1 Autophagy Complex" by combining with multiple proteins to execute related functions. In addition, Beclin 1 involves an interaction with an apoptotic pathway which leads to death of these cancer cells [19]. Therefore, Beclin 1 may become a new cancer suppressor gene as a specific gene for autophagy in mammals [20-22], but the mechanism is unclear. In this study, it is for the first time that we have observed the influ-
A

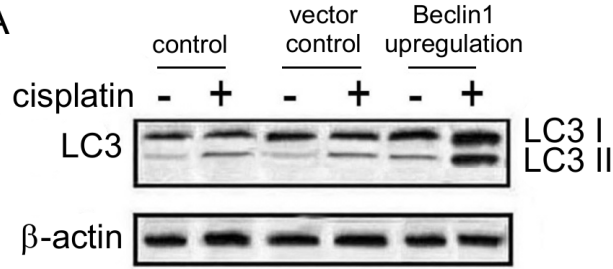

B

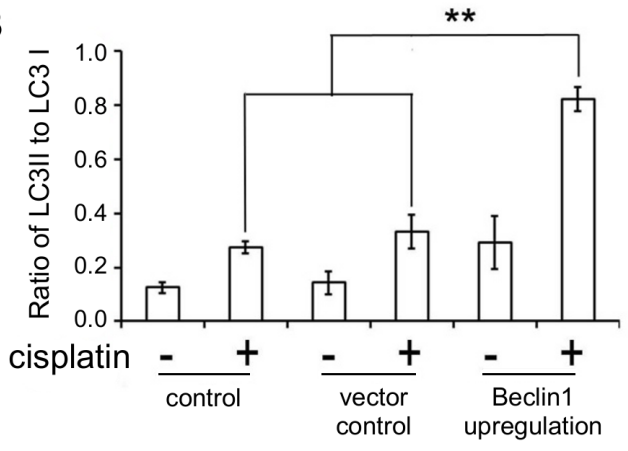

Figure 5. Beclin 1 overexpression enhanced cisplatininduced autophagy. A) The conversion of LC3 in cells treated by cisplatin was detected via western blot. With the cisplatin treatment, an attenuation of LC3-I and increase of LC3-II were observed in three cell groups, and were most obvious in Beclin1 overexpression cells. B) Ratio of LC3 II to LC3 I. The experiments were repeated four times. $\left({ }^{* *} \mathrm{p}<0.01\right)$.
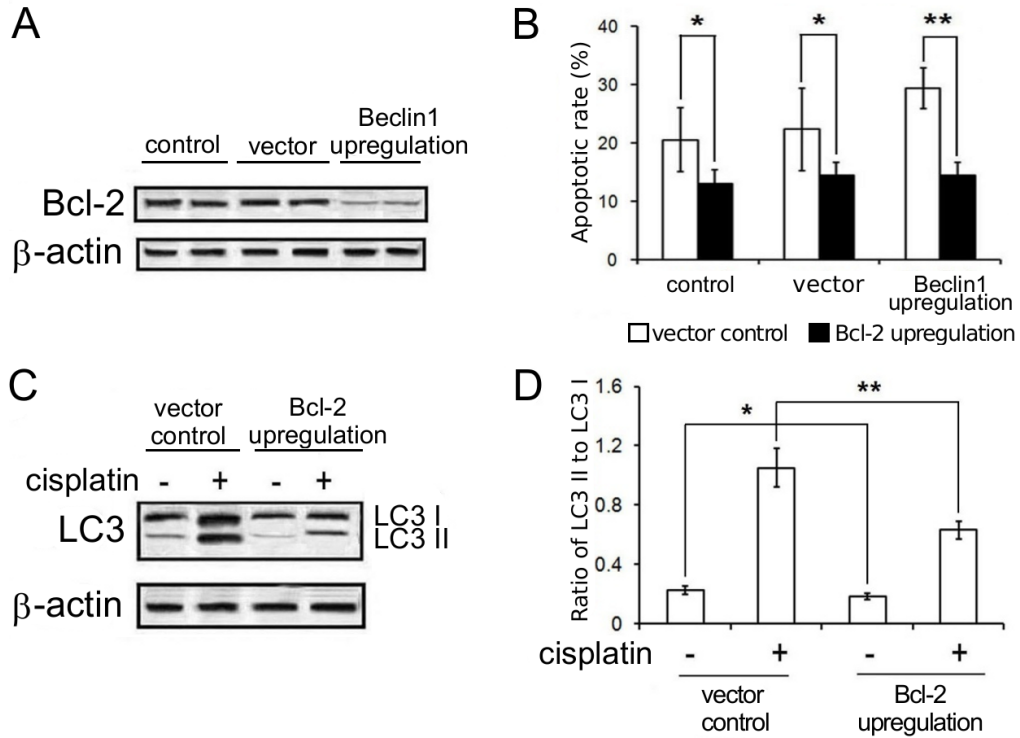

Figure 6. The overexpression of Bcl-2 inhibited the cisplatin-induced autophagy regulated by Beclin1. A) Protein expression level of Bcl-2 was assessed by western blot after Beclin1 upregulation. B) The Bcl-2 overexpression inhibited cisplatin-induced apoptosis in three cell groups and more obviously in Beclin 1 overexpression cells. C) Bcl-2 overexpression decreased LC3 conversion in Beclin 1 overexpression cells, and more obviously after cisplatin treatment. D) Ratio of LC3 II to LC3 I. $\left({ }^{*} p<0.05,{ }^{* *} p<0.01\right)$. 
ence of Beclin1 overexpression on cisplatin-sensitivity in laryngeal carcinoma cells Hep-2 and explored the potential mechanism underlying this effect.

We succeeded in transfecting pcDNA3.1-Beclin1 into Hep- 2 cells and up-regulated the Beclin1 expression significantly. We found that Beclin1 overexpression had no obvious effect on proliferation and apoptosis of the laryngeal cancer cells. In contrast to the results, Ji Young et al observed that Beclin1 overexpression induced autophagy and apoptosis in lung cancer of mice [15]. The different results may be attributed to different cell lines. Although Beclin1 overexpression did not kill laryngeal carcinoma cells, we detected that Beclin1 overexpression regulated cytotoxicity of chemotherapy. The results showed that Beclin1 overexpression enhanced cisplatin-induced killing effects and apoptosis. Similar to our results, Furuya [12] found that overexpression of Beclin1 could enhance cisplatin-induced apoptosis in human gastric cancer cells. The role of autophagy in cell death is unknown. In contrast to our results, Kang et al [23] suggested that functional autophagy in response to CDDP may lead to cell survival of Hep-2 cells, whereas defective autophagy may contribute to CDDP-induced apoptosis in Hep-2 cells. Thus, modulators of autophagy may be used beneficially as adjunctive therapeutic agents during the treatment of laryngeal cancer with CDDP therapy. In our opinion, the difference may be attributed to different interaction between apoptosis and autophagy and paradoxical function of Beclin1. Apoptotic death was inhibited by autophagy in some cancer cells under conditions of nutrient depletion [24]. Conversely, autophagy was required for apoptosis of malignant cells in other researches [25]. It is difficult to clarify the relationship between autophagy and apoptosis, as both of them are induced by similar activation and impact each other's function [19]. There are also many paradoxical views on the function of Beclin1 as well. In the foregoing indications, Beclin1 is used for promoting cell survival. Paradoxically, Beclin1 might also function as a cancer suppressor under specific conditions. For instance, in contrast to our results, Yang [26] down-regulated Beclin1 expression by Beclin1 silencing, and found that the cisplatininduced apoptosis was enhanced in human ovarian cancer SKOV3/DDP cells significantly. However, they also found that overexpression of Beclin1 gene up-regulated chemosensitivity to cisplatin, paclitaxel, 5-fluorouracil, and epirubicin by enhancing therapy-induced apoptosis in the cervix squamous carcinoma Caski cells [27].

Some scholars proposed the relationship between autophagy and apoptosis and had obtained further insights into it. Takacs-Vellai [28] found that Beclin1 represents a link between autophagy and apoptosis and supported the view that the two processes act in a concerted manner in the cell death machinery. In our study, we found that Beclin1 overexpression can decrease the mitochondrial membrane potential and increase the caspase cleavage after the cisplatin treatment. The apoptotic signal is transmitted through extrinsic and intrinsic pathways. The extrinsic pathway is activated in a mitochondrial-independent manner, while the intrinsic one in a mitochondrial-dependent manner. Mitochondrial depolarization begins by cleaving Caspase- 8 , Bid then translocates to mitochondria and activates Bcl-2 family members Bax and Bak. Factors such as cytochrome $\mathrm{c}$ are released from mitochondria into the cytosol to trigger activation of Caspase-3 to induce apoptosis [29]. Furuya [12] found that Beclin1 could raise activity of caspases to enhance cisplatin sensitivity in human gastric cancer cells. Yang [13] found that up-regulated Beclin1 expression enhanced cisplatin-induced apoptosis in cervical cancer cells via the mitochondrialdependent manner. Our findings further confirmed that Beclin1 plays an important status involved in the induction of apoptosis in cancer cells. Moreover, we demonstrate that Beclin1 influences cisplatin-induced apoptosis in laryngeal carcinoma cells by mitochondrial-dependent pathway.

In order to confirm that Beclin1 enhances cisplatin-induced apoptosis via the autophagy pathway, we tested convention of LC3. When autophagy pathway is activated, pro-LC3 (Atg8) is cleaved to form LC3-I, which is then lipoxidized to form LC3-II. It is an important process of autophagy. In our results, Beclin1 overexpression increased convention of LC3, especially after the cisplatin treatment, which suggests that autophagy is the major pathway. Previous researches show that binding of the Bcl-2 to Beclin1 reduces Beclin1's capacity to induce autophagy [30]. However, some other studies show that overexpression of Bcl-2 suppresses the chemotherapy-induced apoptosis rather than the autophagy [31]. In our study, overexpression of Bcl-2 decreased the cisplatininduced apoptosis in laryngeal carcinoma cells with Beclin1 overexpression. Moreover, overexpression of Bcl-2 inhibited Beclin1-induced LC3 convention. The results suggest that in laryngeal carcinoma Beclin1-induced autophagy is Bcl-2 dependent, and $\mathrm{Bcl}-2$ might be used as a regulator of this process. Under the stimuli of external stress, such as chemotherapy drugs, endoplasmic reticulum produces severe stress in tumor cells, which reduces the activity of Bcl-2 phosphorylation mediated by activating pathway signal molecule c-Jun N-terminal protein kinase1(JNK1). Then, Beclin1/Bcl-2 compound decouples, and also the bond between $\mathrm{Bcl}-2$, Bcl-xL and Bax, Bid weakens. Therefore, Beclin1 and Bax were released to play their own role in promoting autophagy and apoptosis, respectively [32]. Thus, under the intervention of cisplatin, Beclin1 not only participates in autophagy of Hep-2, but also promotes apoptosis of Hep-2 by interacting with positive regulatory factors. In conclusion, up-regulation of Beclin1 can increase the cytotoxicity and apoptosis effect of cisplatin via Bcl-2 modulated autophagy in laryngeal cancer. Study has found that $\mathrm{Bcl}-2$ selective inhibitor enhances breast cancer response in combining therapy with tamoxifen [33]. Furthermore, the development of $\mathrm{Bcl}_{2}-\mathrm{BH}_{4}$ antagonist may provide a strategy to improve the lung cancer outcome [34]. Next, we plan to use the Beclin 1 activator or the Bcl-2 inhibitor in research for the treatment of laryngeal carcinoma. 


\section{References}

[1] SANDERSONRJ, IRONSIDE JA. Squamous cell carcinomas of the head and neck. BMJ 2002; 325: 822-827.

[2] BEZERRA DE SOUZA DL, JEREZ ROIG J, BERNAL MM. Laryngeal cancer survival in Zaragoza (Spain): a population-based study. Clin Transl Oncol 2012; 14: 221-224. doi: 10.1007/s12094-012-0787-1

[3] SIEGEL R, NAISHADHAM D, JEMAL A. Cancer statistics 2013. CA Cancer J Clin 2013; 63: 11-30. doi: $10.3322 /$ caac. 21166

[4] KLIONSKY DJ. Autophagy: from phenomenology to molecular understanding in less than a decade. Nat Rev Mol Cell Biol 2007; 8: 931-937.

[5] MIZUSHIMA N, KLIONSKY DJ. Protein turnover via autophagy: implications for metabolism. Annu Rev Nutr 2007; 27: $19-40$.

[6] KLIONSKY DJ. The molecular machinery of autophagy: unanswered questions. J Cell Sci 2005; 118: 7-18.

[7] MIZUSHIMA N, LEVINE B, CUERVO AM, KLIONSKY DJ. Autophagy fights disease through cellular self-digestion. Nature 2008; 451: 1069-1075. doi: 10.1038/nature06639

[8] MIZUSHIMA N. The pleiotropic role of autophagy: from protein metabolism to bactericide. Cell Death Differ 2005; 12 Suppl 2: 1535-1541.

[9] MATHEWR, KONGARAS, BEAUDOINB, KARPCM, BRAY $\mathrm{K}$ et al. Autophagy suppresses tumor progression by limiting chromosomal instability. Genes Dev 2007; 21: 1367-1381.

[10] SCOTT RC, JUHASZ G, NEUFELD TP. Direct induction of autophagy by Atg1 inhibits cellgrowth and induces apoptotic celldeath. Curr Biol 2007; 17: 1-11.

[11] HUANG L, WANG S, LI SS, YANG XM. Prognostic significance of Beclin-1 expression in laryngeal squamous cell carcinoma. Pathol Oncol Res 2013; 19: 771-777. doi: 10.1007/s12253-013-9642-0

[12] FURUYA D, TSUJI N, YAGIHASHI A, WATANABE N. Beclin 1 augmented cis-diamminedichloroplatinum induced apoptosis via enhancing caspase-9 activity. Exp Cell Res 2005; 307: 26-40.

[13] SUN Y, LIU JH, JIN L, PAN L, SUI YX et al. Beclin 1 influences cisplatin-induced apoptosis in cervical cancer CaSki cells by mitochondrial dependent pathway. Int J Gynecol Cancer 2012; 22: 1118-1124. doi: 10.1097/IGC.0b013e31825e0caa

[14] GERMAIN M, SLACK RS. Dining in with BCL-2: new guests at the autophagy table. Clin Sci (Lond) 2009; 118: 173-181. doi: 10.1042/CS20090310

[15] SHIN JY, HONG SH, KANG B, MINAI-TERANI AM, CHO $\mathrm{MH}$. Overexpression of beclin1 induced autophagy and apoptosis in lungs of K-ras LA1 mice. Lung Cancer 2013; 81: 362-370. doi: 10.1016/j.lungcan.2013.05.009

[16] LIANG XH, JACKSON S, SEAMAN M, BROWN K, KEMPKES B et al. Induction of autophagy and inhibition of tumorigenesis by beclin 1. Nature 1999; 402: 672-676.

[17] KONDO Y, KONDO S. Autophagy and cancer therapy. Autophagy 2006; 2: 85-90.

[18] CAO Y, KLIONSKY DJ. Physiological functions of Atg6 /Beclin1: a unique autophagy-related protein. Cell Res 2007; 17: 839-849.
[19] MAIURI MC, CRIOLLO A, TASDEMIR E, VICENCIO JM, TAJEDDINE $\mathrm{N}$ et al. $\mathrm{BH} 3$-only proteins and $\mathrm{BH} 3$ mimetics induce induce autophagy by competitively disrupting the interaction between Beclin 1 and bcl-2/ bcl-x(L). Autophagy 2007; 3: 374-376.

[20] DING Z B, SHI Y H, ZHOU J, QIU SJ, XU Y et al. Association of autophagy defect with a malignant phenotype and poor prognosis of hepatocellular carcinoma. Cancer Res 2008; 68: 9167-9175. doi: 10.1158/0008-5472.CAN-08-1573

[21] WON KY, KIM GY, KIM YW, SONE JY, LIM SJ. Clinicopathologic correlation of beclin-1 and bcl-2 expression in human breast cancer. Hum Pathol 2010; 41: 107-112. doi: 10.1016/j.humpath.2009.07.006

[22] KESSEL D, REINERS JJ Jr, HAZELDINE ST, POLIN L, HORWITZ JP. The role of autophagy in the death of L1210 leukemia cells initiated by the new antitumor agents, XK 469 and SH 80. Mol Cancer Ther 2007; 6: 370-379.

[23] KANG R, WANG ZH, WANG BQ, ZHANG CM, GAO W et al. Inhibition of autophagy-potentiated chemosensitivity to cisplatin in laryngeal cancer Hep-2 cells. Am J Otolaryngol 2012; 33: 678-684. doi: 10.1016/j.amjoto.2012.05.00

[24] BOYA P, GONZALEZ-POLO RA, CASARES N, PERFETTINI JL, DESSEN P et al. Inhibition of macroautophagy triggers apoptosis. Mol Cell Biol 2005; 25: 1025-1040.

[25] TAI S, SUN Y, LIU N, DING B, HSIA E et al. Combination of Rad001 (everolimus) and propachlor synergistically induces apoptosis through enhanced autophagy in prostate cancer cells. Mol Cancer Ther 2012; 11: 1320-1331. doi: 10.1158/1535-7163.MCT-11-0954

[26] SUN Y, LIU JH, JIN L, SUI YX, LAI L et al. Inhibition of Beclin 1 expression enhances cisplatin-induced apoptosis through a mitochondrial-dependent pathway in human ovarian cancer SKOV3/DDP cells. Oncol Res 2014; 21: 261269. doi: 10.3727/096504014X13946388748992

[27] SUN Y, LIU JH, JIN L, LIN SM, YANG Y et al. Over-expression of the beclin1 gene upregulates chemosensitivity to anti-cancer drugs by enhancing therapy-induced apoptosis in cervix squamous carcinoma caski cells. Cancer Lett 2010; 294: 204-210. doi: 10.1016/j.canlet.2010.02.001

[28] TAKACS-VELLAI K, VELLAI T, PUOTI A, PASSANNANTE M, WICKY C et al. Inactivation of the autophagy gene bec-1 triggers apoptotic cell death in C. elegans. Curr Biol 2005; 15: 1513-1517.

[29] GONCHARENKO-KHAIDER N, LANE D, MATTE I, RANCOURT C, PICHE A. The inhibition of Bid expression by Akt leads to resistance to TRAIL-induced apoptosis in ovarian cancer cells. Oncogene 2010; 29: 5523-5536. doi: 10.1038/onc. 2010.288

[30] CIECHOMSKA IA, GOEMANS GC, SKEPPER JN, TOLKOVSKY AM. Bcl-2 complexed with beclin-1 maintains full anti- apoptotic function. Oncogene 2009; 28: 2128 2141. doi: 10.1038/onc.2009.60

[31] NAGAHARA Y, TAKEYOSHI M, SAKEMOTO S, SHIINA I, NAKATA K et al. Novel tamoxifen derivative Ridaifen-B induces Bcl-2 independent autophagy without estrogen receptor involvement. Biochem Biophys Res Commun 2013; 435: 657-663. doi: 10.1016/j.bbrc.2013.05.040 
[32] WEI Y, SINHA S, LEVINE B. Dual role of JNK1-mediated phosphorylation of Bcl-2 in autophagy and apoptosis regulation. Autophagy 2008; 4: 949-951.

[33] VAILLANT F, MERINO D, LEE L, BRESLIN K, PAL B et al. Targeting BCL-2 with the BH3 minetic ABT-199 in estrogen receptor-positive breast cancer. Cancer Cell 2013; 24: 120-129. doi: 10.1016/j.ccr.2013.06.002
[34] HAN B, PARK D, LI R, XIE M, OWONIKOKO TK. et al. Small-Molecule Bcl2 BH4 Antagonist for Lung Cancer Therapy. Cancer Cell 2015; 27: 852-863. doi: 10.1016/j. ccell.2015.04.010 